\section{Applied science to lose out in UK university subject reviews}

\section{London}

A BITTER dispute has broken out between two of Britain's most respected senior academics over the outcome of the recently completed review of university Earth sciences departments, with concern being expressed that departments with a bias towards applied science will lose out in future subject reviews. The rector of Imperial College, London, Professor Eric Ash, says that in the case of his college's geology department the criteria adopted by the review committee were "largely irrelevant" and that by recommending that the department cut its student numbers by 80 , to 175 , and shed 10 out of the 35 academic staff, the committee "got it dreadfully wrong".

Sir Peter Swinnerton-Dyer, chairman of the University Grants Committee, which commissioned the review, defends the review committee's decision. In a letter to Ash he says that the department is perceived as badly managed, that its staff engage in too much consultancy work and that it underachieves in research performance. Furthermore, Swinnerton-Dyer says that publication and citation analyses for the department, the country's largest in Earth sciences, "tend to confirm the national (review) committee's view of the department as complacent and living on past glories".

Responding to this, Ash points out that several influential applied journals are not quoted in the citation index, nor are proceedings of symposia. On the staff's activity in consultancy work, Ash says that the average number of consultancy days a

\section{Nuclear agreement}

Tokyo

THE new and controversial nuclear agreement between the United States and Japan was finally approved by the upper house of the Diet on May 25, and is expected to take effect in the autumn.

The agreement gives Japan approval for 30 years to transport nuclear fuel, most of which comes from the United States, across international frontiers and to reprocess it.

Originally, Japan had planned to return plutonium from European reprocessing plants by air freight, using Anchorage, Alaska, as a refuelling point, which provoked objections in the US Congress. But plans have now been revised and the air transports are expected to fly non-stop to Japan, probably over the North Pole.

Japan intends to transport 25 tonnes of plutonium over a period of 20 years starting in the 1990s, which will require flights every month.

David Swinbanks member of staff does in a year is 10 , with 70 the maximum number for a single member. "Applied geologists are useful to the geology-based industry. Consultancy is financially advantageous to the staff; it is also academically advantageous to the staff and our research students".

Ash says that the case of his college's geology department highlights deficiencies in the review process that will have serious implications for future reviews of university science, distorting the balance between pure and applied science.

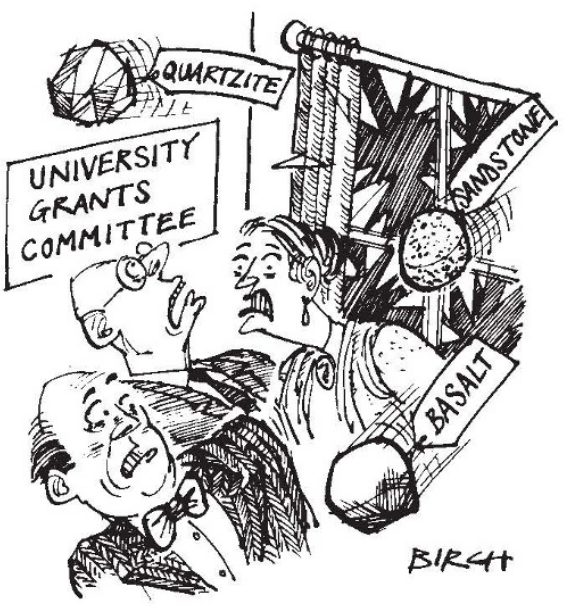

Reviews of physics and chemistry are under way, with biology to begin soon.

When the Earth sciences review was completed in March (see Nature 332, 101; 1988), three categories of department were announced: type $M$ (for 'mainstream'), type I (for 'interdisciplinary') and type $\mathrm{J}$ (for 'joint honours teaching only' and without expensive facilities) Departments of types $M$ and I were further classified into groups 1 or 2 , with the former having provision for greater student numbers. There was general surprise that Imperial's geology department found itself in type I, group 2.

Ash is convinced that by its positioning in group 2 , the department is being penalized for its emphasis on applied research. To support his case, he presents a detailed analysis of performance indicators that he feels are relevant to an applied department. Of the 33 departments reviewed, Imperial scores consistently highly in measures such as earnings per member of staff in research grants and contracts, number of full-time equivalent students, student-to-staff ratio and number of postgraduate students. Ash concludes that the review committee lacked a fundamental appreciation of the working of an applied department. Swinnerton Dyer, however, remains unswayed.

Simon Hadlington
Nuclear arms race at sea

\section{Washington}

To coincide with the Reagan/Gorbachev summit and the ratification of the INF treaty by the US Congress, pressure groups in the United States are trying to focus attention on the nuclear arms race at sea. Thus a report* recently released claims to be the first complete and publicly available inventory of the world's naval nuclear forces.

Nuclear weapons at sea - some 16,000 of them worldwide - make up nearly one third of the world's total nuclear stockpile, according to the report's authors, William Arkin and Joshua Handler, defence analysts at the Institute for Policy Studies in Washington, DC. The authors also contend that increases in the world's seafaring nuclear arsenals constitute a "hidden arms race".

Arkin and Handler are concerned that, while the INF agreement would eliminate land-based intermediate-range nuclear missiles, nuclear arsenals at sea have often been neglected in arms control even as they have become increasingly important in overall nuclear strategy.

The report, which describes the number, type and location of nuclear weapons and nuclear-capable ships and aircraft in the navies of the United States, the Soviet Union, Britain, France and China, explains that nearly half of the world's nuclear naval arsenals are not covered by any arms control negotiations. Among these "uncontrolled" armaments are approximately 3,300 anti-submarine warfare (ASW) nuclear weapons.

Introducing his report, Arkin argued that discussion of the nuclear arms race at sea has been hampered by the lack of accessible authoritative information and that governments have further clouded the issue by secrecy, "neither confirming nor denying" reports of weapons on ships.

The report is especially concerned with the prospects for sea-launched cruise missiles (SLCMs), which it says will be used to replace the intermediate-range missiles to be eliminated by the INF treaty. SLCMs are already a stumbling block in the START negotiations on strategic weapons at Geneva. Describing them as the "most dangerous weapons in production", Arkin says SLCMs are potentially important in regional conflicts.

According to the report, the US and Soviet Union have nearly 550 nuclear SLCMs deployed on 75 surface ships and 94 submarines, with plans to deploy hundreds more on at least twice as many platforms at sea.

Seth Shulman

" "Nuclear Warships and Naval Nuclear Weapons: A Com plete Inventory", Neptune Paper No. 2, May 1988, published jointly by the Institute for Policy Studies and Greenpeace. 